\title{
O corpo simplesmente corpo
}

\section{Resumo}

A corporeidade humana tornou-se um tema que sensibiliza um número grande de estudiosos de diferentes áreas. A biologia, especialmente pelo avanço da genética, oferece os dados mais significativos para alimentar o debate. As ciências humanas, particularmente, a antropologia e a sociologia são as que se alimentam com maior intensidade dessas informações. Este texto, ainda que de forma literária, é um convite para refletir sobre as questões básicas do homem corporal.

Unitermos: Corpo - Corporeidade - História Dominação - Libertação

\section{Abstract}

The human "corpority" became a subject that touches a great number of research of different áreas. The biology, especially by the progress of genetics, gives the most relevant facts to feed the discussion. The human science, particularly, the anthropology and sociology are these ones that feed themselves with more intensity ofthose facts. This paper is an invite to reflect about basics questions of the bodily man.

\section{Introdução}

Para começar vou fazer duas observações. A primeira remete ao tema da corporeidade como uma preocupação pessoal, surgida desde quando fui levado, de maneira um tanto autoritária, a pensar a educação física. Fato que me levou a escrev os textos que tratam das questões da corpor sem entretanto deixar-me satisfeito. A $\mathrm{s}$ observação diz respeito ao VII Congresso $\mathrm{E}$ ro de História da Educação Física, Esporte e Dança. Para situar o leitor vou lembrar da mesa redonda: Resgatando a História do através da Religião, da Mitologia e da Arte. estudo, embora verse sobre questões do cor foi elaborado à luz de um resgate religioso, ou artístico. Além disso ele já vinha anteriormente gestado no silêncio e na de: de minhas indagações.

Uma coisa, No meu estudo há ainda certamente, um agravante, pois não me clara, $a$; estou seguro de que o a mitologia resgate de sua história não libertam $O \mathrm{C}$ se

dê, exatamente, pelos grilhões da caminhos propostos aci-cientificidac ma, religião, mitologia e arte. Não sei se c da religião, da mitologia ou da arte nos $r$ a história do corpo, ou apenas a histó corpos construídos pelos saberes e fazeres três instâncias da vida humana.

Uma coisa, certamente, pareceu-me clarc ligião, a mitologia e a arte libertam o cor grilhões da cientificidade. Elas nos r outras histórias libertárias ou não. Pelo nós, filhos da racionalidade cie poderemos ouvir outras histórias do talvez, capazes de nos mostrar a história pelo corpo. 
O título que eu dei a esta minha exposição é: 0 corpo simplesmente corpo. Esse título teria o objetivo de encontrar o corpo antes de todas as histórias. Caso não cumpra a tarefa que corresponda às expectativas dos organizadores e participantes, pelo menos, espero transmitir a preocupação de quem se esforçou e se esforça para escutar a mensagem proveniente do próprio corpo, antes de passar pelas representações de qualquer ordem.

A metodologia empregada, certamente, não é aquela dos historiadores de carteirinha, dito com mais respeito, historiadores cientistas. Também não posso dizer que seja filosófica, um recurso que eu sempre invoco devido à minha formação acadêmica, porém sem conseguir alcançar a densidade racional que os filósofos profissionais exigem. Em outras oportunidades fui convidado a falar da filosofia do corpo. Não demorei muito para perceber que a filosofia do corpo, da qual eu falava, era, de fato, o corpo construído pelas correntes filosóficas. Ou seja, o corpo que as filosofias desenharam, o que significa dizer, o corpo das filosofias. Há algum tempo tento encontrar a filosofia do corpo, silenciada pelo corpo da filosofia ou das filosofias.

A história da filosofia, na verdade, mostra que somente tratou do corpo porque o logos, a psique, a mente, a alma, a razão ou a consciência não conseguem manifestar-se a não ser pelo corpo. $\mathrm{Na}$ antigüidade e na medievalidade o corpo era apenas o recinto provisório de uma alma aprisionada. Desde Descartes o corpo era apenas uma exigência lógica da existência de um eu pensante. Daí que o corpo ficou, durante muito tempo, um penduricalho antropológico problemático. Entretanto, atualmente, filósofos, psicólogos, historiadores, sociólogos, teólogos, lingüistas, comunicadores, políticos, poetas, artistas etc. mostram inusitado interesse pelo corpo. Os indivíduos em geral, também, entraram na euforia de dedicar-se ao corpo das mais diferentes maneiras. Não sei, com certeza, quais seriam as ra- zões destas preocupações.

Nesta reflexão pretendo dar um passo em direção ao corpo para, num primeiro momen-to, poder ouvir sua fala, para depois ouvir e entender sua história. Por isso, optei por não desenvolver meu discurso através de concei

tos, de definições rigorosas e de metodologias científicas. A linguagem das metáforasl, da arte, da dança e da música, certamente, acredito que é a mais apropriada para que o corpo se expresse. A arte consegue construir corpos sem violentar o corpo vivo. Na dança o corpo pode expressar-se pelo prazer do movimento. Com a música ele sonoriza seus sentimentos. Pela metáfora ele se liberta das prisões dos conceitos e das definições do discuti racional e científico.

Talvez, o corpo não seja uma máquina, nem um cadinho purificador da alma, nem um invólucro da psique, nem um suporte para a razão, nem uma equação matemática, nem uma fórmula química, nem uma organização me-cânica, mas uma obra de arte, uma melodia. Então, a sua história, provavelmente, não seja aquela que contamos. A história que contamos é aquela que narra o tratamento que a racionalidade lhe deu. Se o corpo é melodia precisamos de um ouvido muskal. Caso fosse possível, poderíamos substituir Galileu por Kepler. Enquanto o primeiro transformou a matemática numa linguagem quantitativa das ciências, o segundo queria que ela fosse um meio para entender as melodias dos astros. Assim o universo e o corpo não seriam máquinas e sim sinfonias. Mas como a versão galileana triunfou, hoje nós aqui estamos querendo resgatar a história do corpo através das instituições que as ciências quiseram banir, a religião, a mitologia e a arte.

A primeira atitude para ouvir a história do corpo, no meu entender, consiste em tentar superar a cortina das histórias racionais, teológicas e científicas, para encontrar o alfabeto da língua do corpo. 


\section{As origens da história do corpo}

A narrativa das origens, embora pouco científica, porém, mais sincera, pode iniciar assim: Era uma vez um corpo que era simplesmente corpo. Tudo era corpo ou corporeidade. Não havia outra maneira de ser. Um desses corpos foi reconhecido como sendo o homem. Havia outros corpos, como o dos primatas, dos símios, dos chimpanzés, do gorila, do leão, do elefante, do gato, dos passarinhos, das pedras, das plantas etc. Cada ser destes era corpo, isto é, seu corpo. Então, o homem, da mesma forma, era corpo, só corpo, mas corpo vívente. Mas vívente de uma vida própria. Cada corpo vivente tinha sua vida própria.

O homem, corpo vivente, era mundo. Todos os seres eram corpo. Todos os seres eram mundo. Todos eram, ao mesmo tempo, corpo e mundo. O que os distinguía, além das formas, era a sua corporeidade, isto é, o seu princípio vital ou sua arquitetura vivente, os cientistas diriam, código genético. Cada corpo vivo regia-se pelo dinamismo próprio de sua corporeidade vivente; cada corpo físico regia-se pela sua composição química específica. O mundo era constituído de corpos vivos e corpos não-vivos. Os corpos vivos eram corporeidades autoorganizáveis. A continuidade dos corpos vivos por sistema gerador em que uma parcela, que poderia ser chamada de semente ou ovo, e que possuía a memória de todo o corpo, gerava um novo corpo igual ao genitor. O novo corpo, por um destino interno e em interação comunicativa com o meio ambiente, germinava, crescia e tornava-se uma corporeidade completa em sua especificidade.

Para simplificar a cadeia geradora, talvez, houvesse uma corporeidade primordial, única, da qual se originaram todos os corpos. Podia ser uma corporeidade feita de luz ou de energia. Esta corporeidade luminosa ou energética gerou as corporeidades de todos os corpos, desde os corpos, conhecidos como partículas, corpúsculos, átomos, sub-átomos, poeira cósmica, moléculas, genes, neurônios, células e denominados genericamente de microorganismos vivos ou não-vivos, até os imensos corpos celestes, como os astros, as estrelas, os planetas, os dinossauros, os rinocerontes, as aves, os peixes etc, conhecidos como macroorganismos.

O que diferencia essa infinitude de corpos é sua constituição própria, sua auto-organização, isto é, sua corporeidade. Essa diversidade ilimitada de corpos nada mais é que a escrita real, visível e concreta da história do Universo. A história coletiva da organização de corpos e a história individual de cada corpo são a biografia

geral e particular, desde as origens até hoje, da formação do Universo e

de cada corpo. Tudo está $A$ fonte primordial gravado na herança degarantiu a gênese de cada organismo. E sócada corpo, saber interpretar o que aígarantindo-lhe uma ficou gravado dascorporeidade experiências passadas. O original, pelo corpo vivo é, exatamente, desenvolvimento que essa interpretação. O se dá na ocupação de de sua história desde sua lugares e de tempos gênese. Alguma coisadistintos aparece, apesar do leitor usar uma lente precária, na engenharia genética, a começar com os cromossomos recessivos e a clonagem, para os cientistas; e na teoria das reencar-nações, para os místicos. A contribuição dos cientistas para esta história é cada vez mais impressionante. Basta lembrar o projeto Genoma Humano. Exemplo, mais específico, o parentesco entre etnias diferentes, mas que geneticamente são irmãos. Falo dos Judeus, palestinos, sírios e libaneses, como um dos exemplos mais recentes.

Apesar das múltiplas semelhanças entre os corpos, razão que nos levou a pensar que os corpos humanos geneticamente são todos iguais, na verdade cada corpo é um corpo. Parentesco não é igualdade. Não se repete, para se repetir deveria ocupar o 
mesmo lugar no tempo e no espaço. A identidade absoluta faz coincidir, exatamente um no outro, de tal forma que se torna o mesmo. Nem a clonagem, provavelmente conseguirá tal façanha. Ainda que Baudrillard refira-se a tal possibilidade como o inferno do mesmo, dificilmente haverá uma repetição de um ser vivo já que o intercâmbio com o meio ambiente não pode ser nem predefinido, nem garantir que seja o mesmo do doador. Estar em outro lugar ou em outro momento, é ser outro. O corpo pode ter uma identidade genética, mas o seus processo de auto-organização diferencia-se obrigatoriamente pela interação com o mundo. Os genes se desenvolvem influenciados pelo meio ambiente. A fonte primordial garantiu a gênese de cada corpo, garantindo-lhe uma corporeidade original, pelo desenvolvimento que se dá na ocupação de lugares e de tempos distintos.

Esses dois elementos, espacialidade e temporalidade, que irão preocupar, depois de muitos tempos passados e espaços percorridos, um grupo de corpos que pretendeu emancipar-se do corpo, declarando-se uma entidade extra-corporal. Isto porque o corpo não se esgota nos limites de sua pele, de sua superfície. A corporeidade se estende no tempo e no espaço, melhor dito, ela é tempo e é espaço não apenas uma estrutura de carne e ossos, o que lhe dá possibilidades de construir-se de diferentes formas.

A corporeidade primordial foi inventada, pela fecundidade de sua imaginação criativa, novas formas de corporeidade. Assim os corpos foram se formando, como seqüências ou como rupturas, distanciando-se mais ou menos uns dos outros, devido a um dinamismo herdado da corporeidade primordial, sempre entrelaçados entre si como uma teia de aranha, mas forçados a adaptações ao meio ambiente. Cada um foi inventando formas diferenciadas de manifestarse, isto é, de estar presente, de relacionar-se, de distinguir-se, sem separar-se, da corporeidade originária. Alguns mais sólidos, a exemplo dos cristais; outros mais voláteis, a exemplo da fu- maça. Os primeiros, por serem pesados e mais passivos, são facilmente aprisionáveis; os segundos, por serem leves e fugidios, precisam de armadilhas para serem capturados. Os sólidos mantém uma forma corporal aparentemente estável e imóvel, porque a sua permanência no tempo e no espaço é mais duradoura; os fluídos e os gasosos mostram uma corporeidade maleável, flácida, pode, até, ser desfeita e refeita com relativa facilidade, porque é da especificidade destes corpos.

Ao lado destas corporeidades físicas surgem outros tipos de corpos, cuja corporeidade é dotada de um dinamismo muito mais complexo. São os seres vivos dotados de um sistema próprio de autoorganizar-se. Essa capacidade de autoorganizar-se é própria dos vegetais, dos animais e dos humanos. Cada espécie é constituída de uma corporeidade específica, que, por sua vez, se expande numa infinidade de corporeidades distintas segundo o grau de participação da corporeidade genérica a que pertencem. Assim pode-se constatar um número ilimitado de corporeidades vegetativas, animais e humanas.

Pelos manuais, elaborados em torno da divisão de corpos, ficamos diante de quatro grandes categorias de corporeidades, cronológica e hierarquicamente estabelecidas. Datas e locais foram designados como sendo o tempo e o lugar de seu aparecimento ou formação. Tais categorias são também conhecidos como reinos. Temos, assim, o reino mineral, o reino vegetal, o reino animal e o reino humano. Aceitou-se uma progressão linear de aperfeiçoamento, culminando no corpo humano. De fato, são corporeidades diferenciadas a partir de sua arquitetura e de um processo evolutivo. Todas estão interligadas, mas cada grupo se aperfeiçoa dentro de suas potencialidades. Um grupo não serve de degrau para o outro subir mais. E como o botão de uma flor que desabrocha, que produz a semente. E esta recomeça o ciclo no interior da corporeidade universal.

Se aceitarmos o sentido amplo de vida, podemos dizer que todos os corpos são vivos. 
Habituamo-nos a dizer que os astros tem uma duração mas, hoje, é possível dizer que uma estrela ou um planeta tem vida. Vivos de vidas diferentes. Todos oscilam entre a origem e o fim; entre a composição e a decomposição, entre o nascimento e a morte. Todos possuem três elementos fundamentais, a temporalidade, a espacialidade e a ação. Todo o corpo situa-se num momento e num lugar e desenvolve atividades que lhes são específicas. E o tipo de corporeidade que determina a maneira de estar num lugar e num tempo e o modo de agir. A ação manifesta-se duplamente. Como dinamismo de manutenção de sua organização e, ao mesmo tempo, como princípio de interrelacionamento com as outras corporeidades. Os corpos, portadores de vida vegetativa, sensitiva ou psíquica, são dotados de um sistema de autoorganização o que lhes garante uma autonomia maior no processo de desenvolvimento.

Graças a esse poder de autoorganização surgiram arquiteturas corporais cada vez mais complexas. Quanto maior sua complexidade, maior o número e a qualidade de suas funções. Foi assim que se desenvolveram infinidades de espécies de seres vivos, cada qual com suas funções correspondentes ao seu sistema de autoorganização. Neste cenário o corpo humano organiza-se como o todo de uma espécie de seres vivos. Um corpo que, tudo indica, estaria no topo de um processo evolutivo. Atingira o mais alto grau das manifestações da vida. Ele não precisaria obedecer a nenhuma instância superior, porque, além de ser portador de toda vitalidade dos demais seres vivos, conseguira uma função nova, original. Ele conservou parte da sabedoria vegetativa, manteve boa dose da astucia do instinto animal e adquiriu, o que o caracteriza, o impulso criativo. Pelo impulso criativo recebeu o poder de inventar e de inventar-se, de dar sentido às coisas, de fazer com que tal coisa seja tal coisa, de traçar sua própria identidade e de decidir ser o que ele quer ser. Viver num mundo que ele mesmo cria.
Esse poder criativo da corporeidade humana aguçou a imaginação e, desta maneira, foram traçadas diferentes imagens de homem, e foram criados outros mundos, como sua nova pátria. Nestes projetos de novos homens e de novos mundos, o que é impressionante, o corpo foi gradativamente perdendo participação e presença, chegando a ser esquecido e neutralizado. O próprio poder criador, originariamente gerado e dependente do corpo, proclama-se autônomo. Passa a olhar o corpo como um estorvo, como uma ameaça, como uma tragédia. $\mathrm{Na}$ melhor das hipóteses como um instrumento para os mais diferentes fins, menos o dele mesmo, o de viver.

Depois desta ruptura entre o corpo e seu impulso criador, que recebe denominações diferenciadas em cada cultura e época, a história do corpo deverá ser encontrada nas entrelinhas da história desta entidade, com nomes diferentes, que se instalou soberanamente na corporeidade do ser humano.

A busca do lugar, do tempo e da ação do corpo humano, livre do tempo do lugar e da ação da razão, inspirou o presente relato construído sob os signos da metáfora, do ritmo, da melodia, da dança e da coreografia teatral, em lugar do discurso científico.

\section{A misteriosa história das imagens de homem}

Desde tempos imemoriais que o homem busca saber quem ele é. A última pergunta mais séria sobre o tema, creio eu, foi feita por Kant, junto com outras três perguntas: Que posso saber? Que devo fazer? Que me é permitido esperar? E, por fim, quem é o homem? Afinal, que tipo de criatura é esta que pode saber, que deve fazer e que lhe é permitido esperar? Kant apenas se preocupou com as três primeiras, a última Kant não respondeu.

A filosofia, depois de Kant, perdeu seu estatus diante das ciências empíricas que cresciam na confiança dos pensadores pelo rigor de seus métodos, 
pela objetividade de suas verdades e, particularmente, pela eficácia de seus resultados práticos. Entusiasmado pela ciencia, o homem moderno, deixando de lado a questão filosófica, concentrouse sobre as imagens traçadas pelos grandes ideais que nasciam do conhecimento científico e dos projetos de auto-realização num processo de domínio sobre o mundo exterior. Assim passou três séculos dedicado à construção de objetos $\begin{array}{r}\text { Penso não exagerar } \\ \text { ao afirmar que o }\end{array} \mid \begin{aligned} & \text { científicos que, durante } \\ & \text { muito tempo, acreditou } \\ & \text { serem reproduções fiéis } \\ & \text { do mundo real. O corpo }\end{aligned}$ se conhece não pela humano não escapou das experiência medições desta engenharia existencial de ser científica. corpo, mas pelas representações mudanças cronológicas de cientificas que as virada de século, pode-se ciências lhe oferecem perceber uma concentração de focos das mais variadas luzes sobre a imagem de homem, em parte, motivadas pelo reingresso do corpo na casa (Oikos) humana. O corpo parece estar sendo reconhecido como parte fundamental do ser humano. Esta nova visão antropológica nos conduz a revisar duas questões.

A primeira questão nos obriga a revalidar a pergunta: Quem seria o homem? Um anjo decaído? Um semideus? Um simples mortal condenado à morte como qualquer ser vivo? Um composto binario de corpo e mente? Uma composição ternaria de corpo, mente e espírito? Ou, quem sabe, um mortal sonhador a caminho da imortalidade? E, por fim, a inquietação mais atual, seria a corporeidade a condição específica do ser humano? Simplesmente dita, ser homem é ser corpo?

A segunda questão indaga a quem cabe responder esta questão, que Kant não respondeu? Que ciência seria capaz de resolver esses mistérios que, ao mesmo tempo, afligem e criam espe- ranças na humanidade? Ou não haveria resposta? O homem é a eterna esfinge, representada pela Tragédia de Edipo-Rei? De pouco adianta ao homem decifrar o enigma da esfinge, se esta decifração o transforma em nova esfinge a percorrer os caminhos sem destino? Um eterno Sísifo? As filosofias, as teologias e as ciências nos encheram de conceitos, definições, dogmas e fórmulas sem satisfazer a curiosidade humana sobre sua origem, sua presença no mundo e seu destino último.

No conjunto dos esforços de toda a humanidade para responder a essas indagações, a cultura ocidental, com sua mania de simplificar, reduziu o grande desafio de conhecer-se a si mesmo a uma questão epistemológica. Conhecer, na mente dos sábios e investigadores ocidentais, é uma apreensão inteligível, cognitiva que nos dá uma representação mental do homem. Essa representação passa a ser a mediadora entre nós e a realidade fora de nós. Conhecer-se a si mesmo não é uma experiência existencial, uma vivência, mas uma imagem que se interpõe entre o homem existente e o homem pensante. Instala-se, assim, uma distância entre o homem vivo e o homem pensado, entre o homem que vê e o homem que é visto, embora se acredite convictamente que eles devem coincidir. Trata-se da distância que há entre o sujeito e o objeto do projeto epistemológico cartesiano. $\mathrm{O}$ homem cria de si mesmo uma imagem inteligível, abstrata, uma representação mental e passa a, com ela, identificar-se. Penso não exagerar ao afirmar que o indivíduo julga que se conhece não pela experiência existencial de ser corpo, mas pelas representações científicas que as ciências lhe oferecem.

Nestes novos tempos, diante do fracasso dos sábios do passado, filósofos, teólogos e cientistas, surge a esperança, não de uma nova ciência, mas de uma nova maneira de ver o homem e o mundo, resumida pelo que se poderia chamar de $v i$ são ecológica. Teríamos uma ecologia humana $\mathrm{e}$ uma ética da estética. 
Antes de entrar na reflexão sobre o mérito ou demérito dos procedimentos epistemológicos da cultura ocidental, e antes de sonhar com uma utopia ecológica, quero recorrer a uma maneira diferenciada e estranha de pensar o humano do homem, que nos vem da sabedoria oriental. Julguei que essa maneira de pensar poderia sugerir caminhos diferentes que conduzam à historia do corpo.

Como já sabemos, do Oriente dificilmente nos vêm conceitos, definições, fórmulas abstratas. As culturas orientais nos falam através de exemplos, historias, lendas, fábulas e lições. Assim, diz uma velha lenda hindu que houve um tempo em que todos os homens eram deuses. Mas eles abusaram tanto da sua divindade que Brahma, o mestre dos deuses, tomou uma decisão de lhes tirar o poder divino; resolveu escondê-lo num lugar onde seria absolutamente impossível reencontrá-lo. Esta preocupação gerou um grave problema, onde encontrar um esconderijo absolutamente seguro. Para isso, Brahma convocou um conselho dos deuses menores para juntos traçar um plano de ação. Os deuses menores foram encarregados de localizar o lugar apropriado onde a divindade dos homens deveria ser depositada. A primeira proposta sugeria que a divindade humana fosse enterrada nas profundezas da terra. Não, isto não basta, respondeu Brahma, pois o homem vai cavar a terra e acabará por encontrá-la. Então os deuses, depois de novas conjecturas, retrucaram: Seria mais seguro jogá-la no mais profundo da imensidão dos oceanos. Brahma, mais uma vez, recusou a sugestão por julgar que o homem, um dia, iria mergulhar e explorar o fundo dos mares e poderia recuperá-la.

Diante das recusas de Brahma, os deuses menores concluíram que não saberiam encontrar um lugar mais seguro do que no interior da terra ou nas profundezas dos aceanos. Por mais que pensassem não conseguiam como agradar ao Deus Supremo e reconheciam sua falta de imaginação. Diante desta situação, Brahma não demorou em pronunciar sua sentença: Eis o que vamos fazer com a divindade do homem; vamos escondê-la na maior profundeza dele mesmo, pois é o único lugar onde jamais ele pensará em procurá-la. Desde esse tempo, conclui a lenda, os homens fizeram a volta à Terra, exploraram, escavaram, subiram montanhas, navegaram todos os mares mergulharam em suas águas sempre em busca de algo que se encontra nele mesmo. (Cf. Brandão, Crema-O Novo paradigma holístico: ciência, filosofia, arte e mística p.13).

Evidentemente, toda lenda traz uma mensagem. Ela não descreve um fato histórico em si, mas o significado que o fato anuncia. A narrativa parece indicar que o houve um tempo em que todos os homens era deuses. A minha interpretação é que os homens e todos os seres do universo formavam uma unidade cósmica. Mas os homens aos poucos foram se distanciando e romperam com a harmonia cósmica, na medida em que traçaram para si mesmos uma imagem e um modo de agir pelos quais se separaram e se confrontaram com o universo.

Provocado pela lenda hindu, perguntei-me: será que estou procurando a história do corpo no lugar certo?

Nós, ocidentais, certamente, somos os que mais nos distanciamos deste esconderijo interior, onde está depositada a nossa parcela de divindade, isto é, a nossa identidade humana. Para simplificar, talvez de maneira ingênua, acredito poder exemplificar a distinção existente entre ocidentais e orientais no modo de conduzir o processo de humanização, através de duas atividades bem características. Refiro-me ao YOGA, praticado no Oriente, e o JOGGING, praticado no Ocidente. O primeiro, parece-me, revela a filosofia de vida de grande parte das culturas orientais. $\mathrm{O}$ segundo, por sua vez, expressa com muita precisão o significado da filosofia ativista reinante na sociedade ocidental da era industrial.

A tradição antropológica ocidental nos mostra uma complexa arquitetura humana, inspirada em 
diferentes fontes, que, aos poucos, revela uma total cisão do ser humano consigo mesmo e com o mundo exterior.

Houve um tempo em que, aparentemente, pelo menos para nós ocidentais dedicados às atividades cognitivas, o homem primitivo não estaria preocupado consigo mesmo como objeto inteligível, o que, de alguma maneira, classificamos como um estágio de ignorância. Com certo tom de lamento, concluímos que ainda não se havia chegado a uma representação mental do homem. O homem primitivo tinha, apenas, uma vivência de si mesmo e uma percepção imediata de si e do universo. Ele era, simplesmente, presença, isto é, presente a si mesmo, aos outros e ao mundo. Ser presença significa estar aqui e agora significativamente, intencionalmente. O que equivale dizer: estar neste lugar e neste momento em situação. Na linguagem de Maffesoli significaria estar-junto-com os outros no mundo. Este homem situado sente que está presente, sente os outros, sente as coisas; melhor, convive com elas. Não é uma coisa, porque a esta falta o significado do lugar.

Este tempo, pensando na lenda, seria aquele em que os homens faziam parte da divindade, isto é, integravam harmonicamente a unidade cósmica. $\mathrm{Na}$ tradição bíblica, com forte carga da cultura semita, o homem, de fato, é descrito como uma criatura feita à imagem e semelhança de Deus, e vivia integrado a toda criação. Depois ele descobre que pode ser diferente e superior. Acaba por romper com seu criador e ver a natureza como um conjunto de forças hostis.

Depois disto o homem avançou orgulhosamente nesta sua auto-afirmação e passou a construir para si uma imagem própria que lhe desse poder e glória. Deixou de aceitar-se como corpo que o colocava como um ser do mundo, para buscar uma superioridade que the conferia o poder de ver o universo a seus pés.

Estava, assim, inaugurado um processo de autonomia que levaria a humanidade a romper su- cessivamente com o universo e consigo mesmo. A proclamação da autonomia trazia em seu interior, não a divindade perdida, mas o distanciamento desagregados responsável pelas rupturas internas e externas.

O esforço do homem para criar uma imagem de si, sem dúvida, foi a confirmação do que Brahma previra, segundo o relato da lenda hindu. No Ocidente as conseqüências tornaram-se trágicas. Nem mesmo as ameaças de uma destruição iminente do planeta Terra, comove o homem para demovê-lo de sua fúria destrutiva e autodestrutiva. Cada vez mais sua imagem o afasta de si mesmo e da unidade cósmica.

\section{Os distanciamentos perversos}

Ao falar em distanciamento perverso quero referir-me às separações violentas de um todo em suas partes inseparáveis. Por exemplo, refiro-me à distinção que fazemos entre um eu existencial, concreto, vivido, e um outro eu que me é fornecido pelo conhecimento racional e científico, responsável pela representação mental que devo adquirir de mim mesmo. Assim pode-se falar de um corpo vivido e de um corpo do conhecimento. Quero lembrar, para mostrar o grau de perversidade desta situação, um fato que aconteceu há algum tempo na sala de aula. Estava o professor trabalhando com um grupo de mestrandos sobre o tema de filosofia da corporeidade, quando, buscando saber o que pensavam os alunos, perguntou a um dos presentes que idéia fazia do próprio corpo. $\mathrm{O}$ interrogado desculpou-se dizendo que não poderia responder porque era apenas aluno de graduação. Aí o professor observou que ele deveria ter mais de 15 anos e, durante esse tempo todo, não conseguira formar uma idéia de corpo. Não é preciso dizer que o tom da observação era de espanto, para não dizer que isto seria inadmissível. Como é que ele vivia o corpo sem ter uma idéia do mesmo? A pergunta do professor era 
emblemática no contexto das pedagogias cognitivistas. Ter idéia de corpo é muito diferente de viver o corpo. O espanto do professor pelo fato do aluno não ter idéia de corpo porque seu estudo ainda era pouco, transformou-se em surpresa diante de sua pergunta. Ele fizera uma pergunta da academia. Ela é o lugar das idéias, das representações mentais da realidade. A filosofia, com seu saber conceituai, exigia uma idéia abstrata de corpo. Procedimento próprio do projeto epistemológico. Na escola nos ocupamos de representações mentais.

A conclusão deste fato parece clara, viver o corpo não necessariamente pode ser transformado em idéia. A idéia é o produto cognitivo. Viver o corpo conduz a vivências, a sentir-se, a viver-se. A idéia é uma atividade mental, a vivência é uma atividade existencial. As vivências são uma modalidade de saber que se renovam a todo instante; as idéias fazem parte dos saberes que se adquirem através de um exercício de abstração. Assim, o estudante, até aquele momento, só tivera vivências do corpo, por sorte, ainda não encontrara uma disciplina que lhe dera uma idéia de corpo, ou, talvez, ele ainda não percebera. No que se referia ao seu corpo, a academia, ainda, não lhe ensinara os procedimentos metodológicos para transformar vivências em idéias, conceitos ou definições. Nele, aparentemente, não fora instalado o distanciamento entre o corpo vivido e o corpo representação mental.

Conclusão final. $\mathrm{O}$ aluno não era ignorante, muito menos digno de compaixão. A pergunta do professor é que era idiota, isto é, acadêmica. $\mathrm{Na}$ academia é preciso ter idéia de todas as coisas para ser aceito como sábio.

Para completar essa minha reflexão vou referirme a três instâncias onde se opera o fenômeno do distanciamento. Não quero dizer que sejam objetivamente três ou só três. Trata-se de uma opção, digamos, prática ou funcional.

- A primeira instância acontece na própria pes- soa. O homem se separa em duas partes. Desta separação nascem as diferentes formas de dualismos, já fortemente questionadas e condenadas, embora, não superadas. Toda antropologia ocidental foi definitivamente marcada pela crença de que o homem é psique e soma, alma e corpo, mente e corpo ou, simplesmente, um composto de espírito e matéria. Filosofias, teologias e ciências estão na base destas crenças. Esta constatação é um lugar comum, ninguém discorda que elas foram perversas, mas, por comodidade, falta coragem de renegá-las na prática.

- A segunda instância manifesta-se na distinção, na oposição e na luta do homem contra a natureza. O homem postou-se de um lado; do outro lado, ele mesmo Conclusão final. $O$ instalou a natureza. aluno não era Inicialmente era um ignorante, muito distanciamento de menos digno de nou-se uma atitude decompaixão. A oposição, por fim, acabou pergunta do se transformando em luta professor ê que era aberta e mortal. O ho-idiota, isto é, mem julgou-se no direito acadêmica. $\mathrm{Na}$ e, por vezes, no dever, academia é especialmente em se tratando de sua natureza, preciso ter idéia de dominá-la, neutralizá- de todas as coisas la e explorá-la. A natu-para ser aceito reza tornou-se a grande fonte de recursos entregues ao homem para deles fazer o que bem entendesse.

Este segundo distanciamento cria uma nova situação, pois o homem é dotado de natureza. Mais um problema para agravar o primeiro distanciamento.

- A terceira instância acontece na separação entre os homens dentro da ordem social. Repete-se no social aquilo que acontece nas outras 
duas instâncias, pois as três são concomitantes e conseqüentes uma da outra. Alguns indivíduos proclamam-se superiores, quando não, senhores dos seus semelhantes. Origina-se uma classificação e hierarquização. Há os senhores e os escravos; os civilizados e os bárbaros; os sábios e os ignorantes; os humanizados e os selvagens; os pobres e os ricos. Embora, segundo a ordem da natureza, todos os seres humanos pertençam à mesma espécie e, segundo os princípios da socialidade, todos são proclamados iguais, fica claro que, lembrando o livro $A$ Revolução dos Bichos, aparecem alguns bichos No governo da vida mais iguais que os outros. No governo da vida Assim, todos os homens individual e coletiva são homens, mas há formou-se uma longa alguns que são mais dinastia imperial de homens.

mais de vinte séculos, Diante destas situações e onde se sucederam lembrando várias gerações de reis particularmente a lenda e rainhas hindu, fiquei ainda mais governando, convencido de que devo geralmente, durante pautar minha narrativa séculos ininterruptos e ${ }_{\text {cap uz de me conduzir por }}$ sempre com poderes um caminho ritmado e absolutos metafórico, e não por uma metodologia que me

oferece conceitos e definições. Mais do que uma narrativa de representações mentais da história do corpo, quero tentar projetar uma coreografia dos corpos. Para isso vou me valer metaforicamente da ordem feudal que vigorou na Idade Média. $\mathrm{Na}$ ordem feudal, existe na parte de cima do edifício social a nobreza poderosa, soberana e superior porque irrigada pelo sangue azul e ilustrada pelas luzes do espírito. Na parte debaixo, nos porões da sociedade, forma-se a multidão de escravos e plebeus, humildes e humilhados, pobres e empobrecidos, ignorantes e ignorados, porque portadores da rudeza corporal, desprovidos de aspirações elevadas, dominados por desejos animalescos, carentes de inteligência e mergulhados em atividades ignóbeis. Pelo menos é assim que pensavam os habitantes do alto da pirâmide social. Traduzindo essa situação para a linguagem das ciências e da técnica, falaríamos em desenvolvidos e subdesenvolvidos; a nova nomenclatura para designar os nobres e os plebeus da era industrial.

\section{A dinastia imperial}

Os dualismos antropológicos geraram na vida de cada pessoa uma hierarquia de valores. Os valores espirituais, referentes à psique ou logos, à razão ou mente, à alma ou espírito, caracterizavam o especificamente humano do homem. Eles davam a imagem e a identidade do ser humano. Em nome deles cada pessoa devia organizar sua vida. A eles cabia o comando e o controle sobre todas as manifestações da vida individual, mas sua vigilância maior devia ser aplicada sobre as manifestações do corpo. Os desejos, as emoções, os instintos, as paixões eram vistos como antivalores. As manifestações do corpo eram vistos como resíduos perigosos da herança animal.

Essa mesma hierarquização da vida individual é transferida para a ordem social. Talvez, na cronologia do planejamento social, seja mais correto inverter. A partir de um projeto hierarquizado de socialidade, foi traçado o perfil dos cidadãos que deveriam corresponder às diferentes funções da ordem social a ser implantada. Assim, os homens, portadores com proeminência dos valores mais nobres da natureza humana, tornaram-se os cidadãos superiores em relação aos que eram limitados e identificados pelas forças e valores corporais. Nunca ficou esclarecido quem determinou o primeiro grupo privilegiado por ser dotado de uma psique ou racionalidade superior. Aos componentes desta casta competia exercer o poder sobre os demais, da mesma forma que a par- 
te superior da natureza humana devia dirigir o restante do individuo humano. Em ambos os casos formaram-se dinastias imperiais que sucessivamente exerciam um poder plenipotenciário.

No governo da vida individual e coletiva formou-se uma longa dinastia imperial de mais de vinte séculos, onde se sucederam várias gerações de reis e rainhas governando, geralmente, durante séculos ininterruptos e sempre com poderes absolutos.

Seguindo a genealogía da dinastia imperial, desde a sua origem, encontramos já na Polis grega a entronização do Logos - dinâmica da psique como o soberano absoluto que resumia a verdadeira natureza do homem e princípio de socialidade. E todo aquele que tivesse o desenvolvimento de seu logos, isto é, de sua alma racional, deveria ocupar os lugares mais altos da hierarquia social. A ele cabia o poder de governar e garantir a ordem vigente promulgando leis e aplicando sentenças, premiando os bons e castigando os maus. Em nome dos Logos criou-se o pensamento racional pelo qual definia-se a verdade $\mathrm{e}$ a falsidade, distinguia-se a racionalidade da irracionalidade, e, com isso, assegurava-se o que era o bem e o que era o mal, o que era virtude e o que era vício. Em palavras mais simples, todo aquele, que havia desenvolvido suas capacidades mentais, era tido como o verdadeiro cidadão e, o que era mais importante, tornava-se membro da classe superior. A classe governante que tinha a tarefa de conduzir o povo dominado por almas inferiores, aviltadas e corrompidas pelo predomínio dos humores corpóreos.

Na Idade Média o reino do Logos é continuado pelo reino da Alma, dotada do espírito divino, porque fora criada à semelhança do Deus Criador. Com a ascensão ao trono da Alma acontece também a substituição da idéia de Physis, responsável pela manifestação do Logos da tradição grega, pela idéia de um Deus único. Assim a alma cristã ocupa o trono para conduzir a vida de cada homem individual e social- mente. Ter as virtudes da alma crista era garantia de uma vida superior junto à Divindade Suprema. O que importava para o indivíduo era cultivar a espiritualidade, mesmo que fosse com prejuízos graves para a corporeidade. De nada valia ganhar o mundo inteiro se a alma fosse perdida, esse ditado cristão fazia parte do senso comum da vida cristã. $\mathrm{Na}$ verdade a vida terrena de nada ou pouco valia em si mesma. Seu valor estava estritamente vinculado à felicidade da vida eterna da alma. Para isso era preciso cultivar os valores que desenvolviam a nobreza da alma e sacrificar os valores corporais que podiam desviar para os maus caminhos. Tal objetivo só seria alcançado através de um total controle sobre a vida corporal, descrita como a grande vila do reino da alma. A família real da Alma exerceu um poder absoluto durante, no mínimo, quinze séculos. As suas instituições mais poderosas são as Igrejas e as Teologías

Com o declínio da Idade Média cristã, surge uma nova geração real. O homem ocidental, aparentemente, cansado de suportar os grilhões do reinado da nobreza espiritual divina da Alma, apela para uma nova figura de poder. Então a Razão, com tendências mais humanas, é escolhida e introduzida para um reinado que, parece, não ter mais fim. Sua ascensão ao trono gerou muitos conflitos. Foi violentamente contestada pelo família real da Alma. Ainda hoje suas relações e atribuições não estão bem definidas e muito menos apaziguadas.

Não sei se é legítimo comparar o domínio da Razão, com os reinados anteriores, mas esse parece ser o mais dominador e absolutista da espécie humana. Talvez, o mais trágico, porque seu poder é subtilmente exercido em nome do próprio homem, com a aparência ilusória de ser libertário. A racionalidade, aquela das lógicas matemáticas, torna-se a única instância julgadora do pensar e do agir humano, tanto na esfera pessoal, quanto na coletiva. Tudo precisa ser validado e legitimado pelos princípios 
da racionalidade. É o domínio absoluto da deusa razão. O governo de foro interno e externo pertence às luzes da Razão. As ciências empíricas constituem o legítimo exercício da racionalidade instauradora do conhecimento verdadeiro, com ramificações em todas as instâncias da vida humana. Não há instituição, não há projeto, não há organização, não há decisão, não há saber, não há ação, não há nada que o homem faça sem pedir o consentimento de sua majestade a rainha e deusa Razão. Seu poder onisciente e onipresente se dá através de sua poderosa corte constituída pelas ciências e pela técnica. E por seu intermédio que exerce seu poder absoluto, sempre inapelável. Seu veredicto é definitivo. Somente outro julgamento seu poderá reformular a sentença da verdade anterior.

Não sei se esta resumida descrição da dinastia imperial pode ser vista como uma seqüência de gerações de uma única família imperial, ou se trata de diferentes famílias instauradoras de distintas dinastias. $\mathrm{O}$ fato é que os antigos reis ou rainhas continuam exercendo poderes paralelos ao lado do rei ou rainha que exerce o poder no presente. Talvez, seja mais correto em se falar de confederações, alianças, pactos ou blocos para dividir territórios e manter o poder. Seja como for, o fato fica bem claro que a humanidade hierarquizou os homens, uns dotados de valores superiores e específicos, próximos dos seres divinos; outros, dotados de valores inferiores, permaneceram próximos dos brutos ou dos animais irracionais. $\mathrm{O}$ mesmo esquema sustenta a ordem social. Portanto, se a razão é a instância suprema do indivíduo em sua vida privada; na ordem social, aquele que cultivou as capacidades da racionalidade será o cidadão responsável pela condução do destino histórico da humanidade. Aqueles que não atingiram o grau de desenvolvimento de sua racionalidade, segundo os parâmetros oficiais, acaba formando a grande massa de plebeus, de trabalhadores, de excluídos ou marginalizados. A estes resta a dança dos corpos ou dos escravos nos anfiteatros do tra- balho segundo o ritmo das melodias dos sistemas de produção.

\section{A dança dos escravos}

Na esfera do individual, o corpo é o escravo. Aliás a identificação do escravo com o corpo faz parte de nossa herança latina. Neste sentido quero lembrar uma passagem do Sermão Vigésimo Sétimo, proferido por Vieira para a consolação dos escravos da Irmandade da Senhora do Rosário, na Bahia. Recorrendo ao apóstolo São Paulo, o Padre Antônio Vieira disse: "Falando são Paulo dos escravos e com escravos, diz que obedeçam aos senhores carnais (Efes. VI - 5) E Vieira passa a explicar a frase do apóstolo Paulo perguntando: $E$ que senhores carnais são estes? Todos os interpretes declaram que são os senhores temporais, como os vossos, aos quais servís por todo o tempo da vida; chama-lhe o Apóstolo senhores carnais, porque o escravo, como qualquer outro homem, é composto de carne e espírito, e o domínio do senhor sobre o escravo só tem jurisdição sobre a carne, que é o corpo, e não se estende ao espirito, que é a alma. $\mathrm{E}$ completa Vieira lembrando que, "os escravos, entre os gregos, se chamavam corpos. Tanto que era uso comum, entre os senhores, não falar que tinham tantos escravos, mas que tinham tantos corpos". (Sermões p. 61).

Fica claro que a mente, a razão, a consciência, a alma fazem parte dos senhores da família imperial instalada na esfera da vida pessoal.

$\mathrm{Na}$ ordem social os escravos são todos aqueles que, pelas mais diversas razões, não conseguiram desenvolver suficientemente seu pensamento racional, segundo as regras e exigências da cultura vigente. A nobreza é formada por todos aqueles que conseguiram desenvolver suas capacidades intelectuais, dominando os segredos do conhecimento científico e a arte da técnica. Sabem produzir os conhecimentos verdadeiros, segundo o paradigma da cientificidade vigente, e sabem aplicar os mesmos conhecimentos no exercício do poder para manter a ordem sócio-cultural. 
Nesta exposição eles se tornam os controladores do ritmo da dança dos escravos.

Pelo que foi dito fica claro que a dança dos escravos se dá, tanto na ordem social, quanto na vida privada. Em ambos os casos pode-se identificar três elementos fundamentais para que a dança possa acontecer.

\section{A orquestra}

O primeiro elemento da dança dos escravos é a orquestra. A composição das orquestras são variadas. Elas se formam com instrumentos de sopro, de cordas, de percussão; reúnem regentes, músicos, instrumentistas, vocalistas etc. Da orquestra depende o espetáculo. Mas o ritmo da dança depende das partituras executadas. A coreografia da dança depende da melodia e do ritmo das peças musicais. Neste sentido, nada mais significativo do que lembrar a expressão popular: ¿preciso dançar conforme a música.

Em última instância, a dança depende dos donos da orquestra. Esses donos são a família real, a nobreza, as elites e, para não esquecer a temível palavra, as classes dominantes, cujos representantes são os governantes, políticos, intelectuais, cientistas, professores, empresários, juizes, teólogos, moralistas. Numa palavra, são todos aqueles que participam, mais ou menos, das relações de poder seja econômico, seja político, seja científico, seja religioso.

\section{As partituras}

O segundo elemento é constituído pelas partituras executadas. Os passos, as evoluções, a coreografia precisam acompanhar o ritmo e o sentido das músicas que a orquestra apresenta. Essas partituras são feitas não de notas musicais, sustenidos ou bemóis, mas de valores culturais, religiosos, estéticos, econômicos, ideológicos, políticos ou científicos; de desigualdades, opressões, injustiças, violências, exclusóes e explorações. As músicas têm múltiplas e variadas fontes de inspiração segundo o interesse que as fi- nancia. Todas elas, entretanto, possuem um ponto comum central, é a manutenção do poder da dinastia imperial.

\section{Os bailarinos}

Os bailarinos formam o terceiro e mais importante elemento desta dança dos escravos. Aqui se encontram mais ou menos dois terços da humanidade. São todos os excluídos pelo processo de desenvolvimento, a começar pela democracia ateniense, passando pela religiosidade medieval, continuando pela modernidade tecno-científica da era industrial, até alcançar a onda avassaladora da globalização. E a imensa multidão de pobres, desempregados, famintos, mendigos, velhos, analfabetos, crianças de rua, sem-tento, homossexuais, prostitutas, negros, índios etc. Enfim todas as minorias excluídas, pelo donos da orquestra, de participar efetivamente da vida sócio-cultural e econômico-política de sua ordem social.

Os três elementos da dança dos escravos reúnemse nos salões dos sistema de produção onde, todos os dias, os espetáculos acontecem. São especificamente organizados segundo o tipo de dança a ser praticado. No princípio, esses salões eram as galeras, as áreas agrícolas, os campos de guerra, os templos dos deuses que exigiam sacrifícios humanos, as casas de prostituição, as arenas, as periferias das cidades, lugar dos pestilentos. Depois surgem outros tipos de salões como as prisões, os asilos, os hospitais psiquiátricos, as minas de extração. Por fim, aparecem os salões mais sofisticados. As indústrias, as empresas, as fábricas, os escritórios, os ginásios esportivos, as quadras de esportes, as pistas de atletismo, as passarelas dos desfiles de moda, as câmeras de televisão etc.

Nestes últimos salões, devo reconhecer, os escravos parecem aceitar livremente a escravidão como se ela fosse a sua libertação. Julgam-se emancipados com o valor do salário, com o estatus, com a vitória, com o recorde, com a medalha. O estado do corpo não importa. Aí está a grande astúcia da deusa e rainha racionalidade. $\mathrm{O}$ seu processo 
de racionalização consegue justificar tudo.

A questão a ser colocada, no meu entender, é de saber se é possível acabar com a dança dos escravos? Os salões teriam uma porta de emergência de saída? Mais, haveria disposição e força para destituir a dinastia imperial? Qual o caminho da liberdade ou do resgate do corpo? Daria para falar em festivais de libertação como uma possível I solução? Que festivais e quem os organizaria?

\section{Os festivais de libertação}

Vou falar dos festivais libertários, segundo minha percepção, que acontecem na atualidade identificada, ainda que de maneira polêmica, como sendo pós-moderna ou pós era industrial. Penso poder concentrar esses possíveis festivais em três pontos.

\section{A reforma de pensamento}

O primeiro festival poderia ser promovido através da reforma de pensamento. As filosofias, as ciências e as teologías tradicionais, certamente, não têm condições de promover tais festivais, pois foram responsáveis pela instalação das dinastias imperiais e da dança dos escravos. A racionalidade simplificadora, desenvolvida pelo pensamento ocidental, necessita de uma reforma de pensamento, diz Edgar Morin. Essa reforma aconteceria, segundo ele, quando surgir um pensamento que ligue o que está separado e compartimentado, respeite o diverso ao mesmo tempo que reconhece o uno e que tente discernir as interdependências. Esse pensamento deverá ser radical, multidimensional e sistêmico, capaz de conceber a relação do todo com as partes e das partes com o todo. (Terra-Patria p. 167).

Essa reforma é uma das tarefas a ser feita por aqueles que desejam iniciar, de fato, o primeiro festival de libertação, que começa por questionar o monopólio do poder da racionalidade, através da restauração de outros poderes alternativos, como o da sensibilidade, do sentimento, da intuição, exatamente, aqueles radicados na corporeidade.

A idéia do filósofo edificante, proposta por Richard Rorthy, pode fortalecer a reforma de pensamento de Edgar Morin. O trabalho do filósofo edificante é essencialmente reativo através de sátiras, paródias ou aforismos; ao contrário dos filósofos sistemáticos que são construtivos e oferecem argumentos, querendo colocar-se na trilha segura de uma ciência e, como os grandes cientistas, constróem para a eternidade. Os filósofos edificantes destroem em benefício de sua própria geração e sabem que seu trabalho perde sentido quando o período contra o qual se insurgiram já terminou. Eles desejam manter o espaço aberto para o sentido de admiração - admiração de que haja algo de novo sob o sol, algo que não é uma representação acurada do que já se encontra ali, algo que não pode ser explicado e mal pode ser descrito. (Cf. Richard Rorthy - A filosofia e o espelho da natureza p. 362).

A programação do primeiro festival libertário pode completar-se com a figura do pensador orgânico, apresentada por Michel Maffesoli. Seu trabalho é acompanhar aquilo que se vive. Ele está mais próximo da vida do povo e se põe na escuta daquilo que é vivido. Seu conhecer não é uma representação de objetos, mas um nascer com, exatamente o que diz a etimologia latina. (Cf. O Conhecimento Comum e Rev. Geempa n. 3, p. 20-21))

No festival da reforma de pensamento abrem-se espaços para outras formas de pensar, para outros tipos de saberes, para outros tipos de pensadores que não obedecem às normas dos saberes da racionalidade científica. Existem outros saberes construídos fora da cientificidade e fora da razão. São os saberes, do poeta, do curandor, do paranormal, do benzedor, do deficiente mental.

Uma vez reconhecida a viabilidade do primeiro festival proclamando as possibilidades de outros saberes e de outros "cientistas", pode-se garantir um segundo tipo de festivais. 


\section{A corporeidade}

O segundo festival pode acontecer com a proclamação do corpo como a condição humana. $\mathrm{O}$ homem é corpo. Isto significa dizer ser corpo, em lugar de ter corpo. Evidentemente isto não significa limitar a corporeidade humana ao conceito de matéria da física antiga e moderna. O princípio de ser corporal obriga a reconhecer o homem como um ser dotado originariamente de sensibilidade e de existência, no sentido heideggeriano, de um ser situado num lugar e num momento. Todos os valores negados pela racionalidade, como impróprios para a humanidade do homem, tornam-se exatamente o ponto de partida de sua identidade. Strawson garante que os primeiros particulares de base são os corpos, porque eles satisfazem a título primário aos critérios de localização no único esquema espaço-tempo. Essa prioridade, diz Paul Ricoeur, reconhecida nos corpos, é de maior importância para a noção de pessoa. E Merleau-Ponty conclui que o correto é dizer: "eu sou corpo, e não, eu tenho corpo".

Neste festival o corpo tem voz ativa. Não é mais a razão a coordenadora das atividades festivas. Também não é excluída, mas apenas uma convidada, pois sua presença só é possível graças à corporeidade, da qual faz parte e da qual é uma expressão, talvez, a mais eloqüente.

Quanto mais se olha para o homem e sua história, mais se reconhece que é um ser corporal. Já que uma das preocupações desta mesa redonda é resgatar a história do corpo pela religião, vou invocar alguns traços da religiosidade cristã, mesmo que seja pouco ortodoxa, talvez, tenha traços das heresias.

O fato primeiro da era cristã é a encarnação do Filho da Suprema Divindade Bíblica. O evangelista São João usa a expressão, "O Verbo se fez carne", para afirmar que o Enviado de Deus-Pai havia assumido a condição de ser humano. Não diz que se fez homem, mas carne. A Segunda Pessoa da Trindade tornou-se corpo, esta seria, portanto, na minha interpretação, o modo de ser do ser humano. Até ai, acredito, nada de novo. Os teólogos e comentaristas cristãos, quase na sua totalidade, exaltam o gesto de dedicação, de humilhação e de amor de um Deus feito homem, para com a humanidade perdida e pecadora. Dificilmente se encontra alguém perceber no gesto da divindade encarnada, uma reabilitação da corporeidade humana. Este continua corrompido, pecador e condenado ao destino da via crucis, do Calvário e da crucifica-ção. Sua glorificação só virá, muito tempo depois, quando se reencontrar com a alma na Glória eterna junto a Deus.

Há ainda outras passagens bíblicas que, no meu entender, poderiam No festival da reabilitar a dignidade do reforma de corpo como a identidade do ser humano. Lembro pensamento abrem-se que continuo a minha espaços para outras hermenêutica bíblica nãoformas de pensar, autorizada oficialmente. para outros tipos de Boa parte dos grandes saberes, para outros feitos de Jesus pelos ca- tipos de pensadores minhos da terra tem as que não obedecem às condições do corpo como normas dos saberes o alvo preferido. A da racionalidade peixes foi para saciar a científica.

fome. O Sermão da montanha anunciam as bem-aventuranças para amenizar os sofrimentos existenciais. A maior parte dos milagres curam males corporais, num momento chega a anular a morte. E para completar a idéia de corporeidade, por várias vezes, lembra que ela não se esgota na materialidade, mas também no amor a Deus e ao próximo. A corporeidade é uma relação amorosa.

Tal dimensão da corporeidade para o outro pode proporcionar mais um modalidade de festivais libertários. 


\section{A socialidade corporal}

O reconhecimento da corporeidade como a condição humana inspira um outro tipo de socialidade que se desenvolve no espaço do doméstico, ou seja, o espaço primeiro da corporeidade. O social doméstico se constitui pela proximia, pela presença, pelo contato, pela convivência. E estar-junto com o outro, sentir e sentir-se mutuamente comprometido num destino comum. A sensibilidade é o cimento, diz Maffesoli, desta nova socialidade, onde impera a solidariedade orgânica e se instaura a ética da estética.

Além disso, a socialidade corporal reabilita o prazer como um valor antropológico tirando-o da esfera da moral. Assim a festa, o espetáculo, a arte, a dança, o teatro são os novos referenciais para animar uma nova ordem social, lugares apropriados para a emoção, o afeto, o táctil e o estarjunto-com. (Maffesoli O Tempo das Tribos p. 111). Evidentemente, não se trata de um corpo racionalizado, mas um corpo sensível, que pode ser tocado, um corpo que eu construo, diz Maffesoli, sob o olhar do outro e para que ele possa ser olhado pelo outro. E continua, "Creio que essa idéia de construção do corpo é uma das primeiras manifestações dessa ética da estética", que, no meu entender, torna-se a grande responsável pela socialidade doméstica, o salão mais emblemático da libertação dos escravos.

\section{Conclusão}

O resgate da história do corpo, para ser coerente com o minha reflexão, somente será possível quando conseguirmos transcrever a sua fala. E o corpo fala. Sempre falou. Quase nunca foi ouvido. Reduzido ao silêncio, mas no seu retiro silencioso, ele envia constantemente suas mensagens. Vou deixar de lado autores conhecidos, como Merleau-Ponty no capítulo $O$ corpo como expressão e a fala, ou Rubem Alves $O$ corpo e as palavras, ou Pierre Weil e Roland Tompakov $O$ corpo fala, ou Thérèse Bertherat $O$ Correio do Corpo, e prefiro recorrer a um depoimento de um dos grandes atletas brasileiros do tênis, Thomaz Koch. Seu depoimento tem o título Nosso amigo corpo. Começa assim: "E incrivel como o nosso corpo está sempre transmitindo mensagens, que entendemos ou não". A seguir refere-se aos problemas de cansaço a que chegam muitos tenistas, como o caso recente de Guga que teve de abandonar um torneio internacional. E Koch analisa o fato desta maneira: "Qual o sentido $e$ qual a lição que podemos tirar? Para mim, parece claro que eles não escutaram o alarme, a voz interna pedindo um tempo maior para descansar entre os torneios'. Eu acrescentaria, o termo alarme é sempre um aviso de perigo, portanto mais forte, mais audível, e, assim mesmo, não se atende. Imagine, então, a escuta da fala diária quanto mais difícil será!

Voltando ao nosso resgate da história do corpo, talvez, percebamos que ele esteja pedindo que o deixemos falar, contar a sua história, porém, seu discurso e sua narrativa histórica, certamente, não é feita de conceitos, de simetrias dialéticas, de raciocínios lógicos, mas da aleatoriedade da ludicidade, da alegria da festa, da satisfação do prazer, da sabedoria dos instintos, dos desejos dos sentidos, do incômodo da dor, da pressão da fome e da sede, da carência do carinho, do peso do trabalho, do desgaste da fadiga, enfim, de toda uma linguagem que não usa abstrações, mas se traduz nas vivências de cada momento de sua existência. Seu olhar, suas expressões faciais, seus músculos, seus ossos, sua circulação, sua respiração, sua sexualidade, sua pele, seus sentidos, sua temperatura, seus órgãos são os painéis, ou as telas de vídeo ou os monitores do computador onde se inscreve sua história. Falta apenas um leitor que abdique, por um momento, de ser o homo sapiens para ser o homo ludens, que substitua os olhos da razão pelos olhos da sensibilidade, que transforme a visão objetiva do cientista, pela intuição subjetiva do poeta. 


\section{Referências Bibliográficas}

1. BAUDRILLARD, Jean. A Transparência do mal.

Campinas SP, Papirus, 1992.

2. CREMA, Roberto. Saúde eplenitude: um caminho

para ser. S. Paulo, Summus, 1995.

3. MAFFESOLI, Michel. O Tempo das Tribos. Rio

de Janeiro, Forense, 1987.

4 o Conhecimento Comum. S.

Paulo,

Brasiliense, 1985.

5. MERLEAU-PONTY, Maurice.

Phénoménologie de

Ia perception. Paris, Gallimard, 1945.

6. MORIN, Edgar. Terra-Pátria. Porto Alegre, Sulina,

1995.

7. RICOEUR, Paul. O Si-mesmo como um outro.

Campinas SP, Papirus, 1991.

7. RORTY, Richard. A Filosofia e o espelho da natureza. Rio de Janeiro, Relume, 1994.

8. VIEIRA, Antônio Padre. Sermões. S. Paulo, Cultrix,

1995.

\section{Notas}

Silvino Santin é professor e orientador do Programa de Pós-Graduação em Ciências do Movimento

Humano

Mestrado/Doutorado da ESEF/ UFRGS. 
74 Wovimento 